\title{
Nabokov's Cinematic Afterlife
}

\author{
By Żaneta Jamrozik
}

\section{Spring 2013 Issue of KINEMA}

Glancing at the title of Ewa Mazierska's Nabokov's Cinematic Afterlife one might expect a book favouring a traditional approach to adaptation studies. The title pointing to the name of Vladimir Nabokov, suggests that the writer and therefore literature occupies the centre of this study. Then, a look at the book's table of contents may assure the reader that he or she is about to read eight essays, each focused on only one film and (as one is likely to believe) one Nabokov novel. This rule of comparison seems to be in effect until the ninth chapter titled simply Vladimir Nabokov and Jean-Luc Godard. However, more detailed examination of the contents reveals that among the first eight chapters only the last one mentions the name of Nabokov and the title of his short story, The Assistant Producer, although places it beside Triple Agent, a film written and directed by Eric Rohmer. The fact that the chapters from one to seven cite only the titles of screen adaptations of Nabokov's novels, as well as their eponymous 'cinematic afterlife', implies that the presence of the famous writer is indeed of great importance here, although only as long as it is a cinematic presence. Therefore it is not simply a presence created in or through cinema, but presence as cinema: existing in the beam of light, and linking the past with the present by the reiteration of images.

The book puts an emphasis on the relation between fiction and reality, and on the process of adapting Nabokov's fiction to say something important about reality. This approach is announced already in the brief introduction, where Mazierska writes that, 'I shall admit that I was most influenced by those authors who argued that there is more to Nabokov' s prose than metaliterary pursuits - who see in this author somebody deeply interested in reality ("reality" or "realities") (8)'. Again, for readers familiar with Nabokov' s notorious insisting on separateness of literature and reality, this passage may come as a surprise, but we should remember that opinions frequently expressed by the writer in interviews were equally often questioned in his novels.

The theme of life becoming structured like fiction appears in the very first chapter, which focuses on film adaptations of Nabokov's Lolita. The chapter takes into account both the novel and the history of its reception, then proceeds to examine the adaptations by Stanley Kubrick and Adrian Lyne. The last section moves beyond the traditional notion of adaptation to present links between Lolita and films like American Beauty by Sam Mendes, Roman Polański's Tess or even David Lynch's Twin Peaks: Fire Walk with $M e$. The whole chapter is highly informative, presenting in a more detailed manner subjects mentioned in the introduction, and putting together many themes which will become recurrent throughout the book.

Most importantly however, it explains why the notion of fidelity is still significant for adaptation studies, and how it can be set in motion by intertextual reading. The author begins by pointing out that even though it is unfaithful to the novel, Kubrick' s Lolita is perceived as the 'original' when compared to Lyne' s adaptation, because of its air of nostalgia and the high esteem of its director. Using the notions of fidelity and author/auteur the chapter shows, that while the relation between Kubrick' s and Nabokov' sLolita can be called harmonious, as both gain from it an artistic recognition, the second adaptation cannot compete with its two famous predecessors. Therefore Lyne becomes trapped within his merely well-crafted' image, confirmed by his too faithful to the book adaptation.

Because the chapters are not arranged chronologically but thematically, they allow the reader to notice how they interact with each other. The book shows not only the differences or similarities between Nabokov's novels and their adaptations, but also presents different methods of adaptation directed at different aims. For example, Kubrick' s 'posh' Lolita presents itself as a sophisticated piece of art, while Lyne's 'ethnographic' adaptation tries to achieve as much by being as close to the novel as possible. While this type of structure leaves out the idea of tracing the line of development between examined films, a thematic link between the chapters can be found quite easily, as they all put emphasis on similar subjects or propose contrapuntal readings to those mentioned earlier. For example, the paradox of fidelity returns in chapter four with the examination of Rainer Werner Fassbinder's Despair, where we read that 'Despair is an interesting example of film adaptation where staying "faithful" to the letter of the original work results in making a film very 
different in its ontology (103)' . This simple but crucial 'ontological' difference would be uneasy to spot without asking questions of fidelity.

The second chapter explores Tony Richardson's adaptation of Laughter in the Dark, and like the previous one begins with Nabokov's novel. This pattern is followed in subsequent chapters, each one opening with an exploration of literary texts and contexts, then focusing on screen adaptation. By that structure the book answers 'critical neglect' mentioned in the introduction, where we read that 'the relationship between Nabokov' s work and cinema is a subject of numerous studies and comments, but the focus of this type of scholarship until recently has been on the cinematic influences on Nabokov' s books' (4). Nabokov' $s$ Cinematic Afterlife tries to reverse the way the famous writer is usually linked with cinema, and examine how his artistic persona, his views on art and his novels become an inspiration for filmmakers, rather than the other way around.

Although this method is expressed also in the recently published 'David Cronenberg: Author or Filmmaker?' by Mark Browning, the books seem to reach quite opposite conclusions. Browning is interested in tracing literary influences in Cronenberg' s cinema. His research is limited to the works of three writers: J. G. Ballard, William S. Burroughs and Nabokov, whom he finds particularly important for the Canadian director. Like Mazierska he goes beyond exploring 'rigid adaptation' and devotes a whole chapter to the relation between Cronenberg's eXistenZ and Nabokov's Invitation to a Beheading and Bend Sinister. Although his readings offer many intertextual links between the novels and films, he uses them more traditionally as proofs to back up his words and explain Cronenberg' s works quite definitively. Whereas in the chapter devoted to Laughter in the Dark we do not find any kind of meaning to be proven by comparing or contrasting. It is more of an attempt to read both the novel and the film as 'children of their times', by pointing to the changing of their milieus from 1920s Berlin to 1960s London.

The third chapter devoted to Jerzy Skolimowski' s King, Queen, Knave also explores cultural dislocation, although in a slightly different manner from Richardson moving the action of Laughter in the Dark to his native London. It begins with pointing out the similarities between the emigration biographies of Nabokov and Skolimowski. This, as we read, affected their staying in Germany, and in the case of Skolimowski resulted in him creating a much more abstract film than the one made by Richardson. However, as the chapter's title (Nabokov, or the Logic of Late Capitalism) illuminates, Skolimowski' s abstract tale also lends itself to a practical reading. However, in my opinion, the most interesting example of employing the concept of cultural dislocation to intertextual reading of Nabokov's adaptation is presented in chapter six. It not only situates Valentin Kuik's An Affair of Honor within the contexts of contemporary Estonia, but also explores the similarities that the recently independent country shares with Nabokov's W eimar Republic. Furthermore, it shows how the adaptation of a story that seems today anachronistic or 'unrealistic', with duels of honour quite out of fashion, reflects the sense of displacement characterising the main protagonist, as well as contemporary Estonia.

Chapter eight, rather than comparing Nabokov's The Assistant Producer with Rohmer's Triple Agent (with both retelling the real-life events surrounding the 1937 disappearance or kidnapping of Evgenii Miller) to discover whose version of the story is more likely to be the truh, takes this opportunity to present them as equal interpretations of the event. This enables the author to go further than comparing both works, to focus on the similarities between methods of intertextualization of stories and textualization of history.

The fifth chapter, devoted to Jérôme Foulon's Mademoiselle $O$, in an interesting way continues to explore the theme of women perceived, recalled and ultimately transformed into a work of art by a male artist. At the same time, reading Foulon's film against the portrait of Nabokov's Swiss governess taken from chapter five of his autobiography, Speak, Memory, repeats the questions already posed with regard to Lolita, asking the extent to which Nabokov is similar to Humbert in his dealings with the governess.

Chapter seven takes the feminine theme even further with The Luzhin Defence by Marleen Gorris, which is the only film directed by a female to be discussed in the book. It begins with the assertion that too much emphasis has been put on the chess-art analogy in Nabokov's writing, and that The Luzhin Defense(as this is the title of the novel) 'illustrates the limit' to which they are similar. In Gorris' film, as Mazierska argues, this limit is adequately conveyed by the sensuality evoked through the breathtaking setting derived from 'heritage cinema', and by giving her protagonist another 'hobby', as Gorris' Luzhin, apart from being 
a chess master, can dance.

However, the chapter's exploration of sensuality in Gorris' adaptation and the equal weight given to the motif of 'intellectual' chess and 'emotional' communication through dance makes this chapter an exception, as the intellect and precision of chess prevail throughout the book. Referring to the subtitle of the introduction, The Pleasures and Dangers of Adapting Nabokov, I must admit that, although Nabokov's Cinematic Afterlife succeeds in presenting intellectual pleasures to be gained from Nabokov's books and their adaptations, it somewhat neglects the sensual side of their experience. The last chapter, brilliantly comparing Nabokov's and Godard's approaches to literature and language among others, is omitting the issues which I would have expected, like the experience of image, sensual memory, or synesthesia. This, however, does not affect the book's value for the growing field of adaptation studies. The main merit of Nabokov's Cinematic Afterlife lies in the way it turns theory into practice, showing in the course of readings how troublesome notions of fidelity, authorship or intertextuality can still beapplicable.

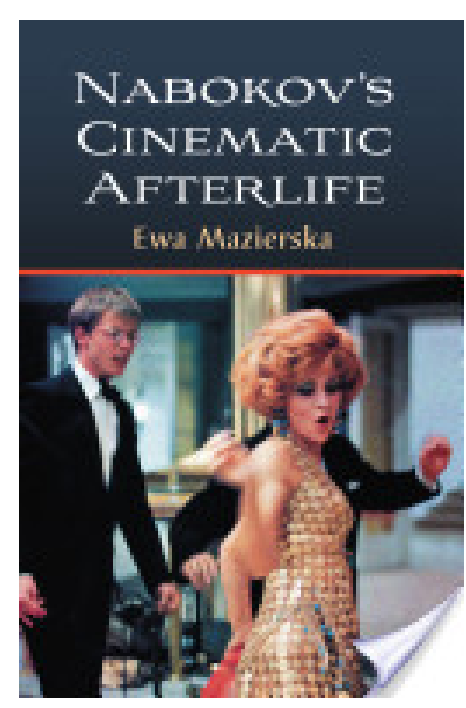

Figure 1: EWA MAZIERSKA:NABOKOV'S CINEMATIC AFTERLIFE: THE PLEASURES AND RISKS OF ADAPTATION. McFarland, 2011. List: \$45.00. ISBN: 9780786445431.

\section{Author Information}

Żaneta JAMROZIK is a PhD candidate at the Jagiellonian University in Krakow and at The University of Central Lancashire in Preston. She is working on Michael Haneke's cinema and Eminem's music videos. She has published in the Intellect journal Studies in Eastern European Cinema. 